\title{
The Names of God and the Dating of the Biblical Corpus
}

Yoel Elitzur

\section{Biblical Criticism and the Dating of Biblical Sources-A Brief Survey}

The "documentary hypothesis," the most famous theory of critical biblical scholarship, originated in the eighteenth century from the examination of what appeared to be contradictions and repetitions in biblical stories and legislation. Scholars concluded that the Torah is comprised of four primary sources that differ from each other in language and content. Two of these sources are called after the names of God that characterize them: source "J" frequently uses the Tetragrammaton YHWH (in old scholarly literature "Jehovah" erroneously following the seemingly masoretic punctuation of this divine name), while source "E" uses often the name Elohim. There are two additional sources: "P," the Priestly source, which discusses sacrifices, ritual, and the priesthood, and favors numerical sums, and "D," the source of the book of Deuteronomy. Several chapters in the early prophets are also attributed to the Deuteronomic school. "D" mandates the centralization of the ritual in a location to be chosen by God, and takes special interest in the subject of exile and redemption and the fate of the Israelite people. Scholars usually date "D" to the end of the First Temple period and "P" to the Second Temple period.

There have been, and continue to be, many adherents of these theories. There have also been many opponents-primarily, but not exclusively, Jewish and Christian religious fundamentalists. The greatest of the contributors to the documentary hypothesis in the nineteenth century was Julius Wellhausen. The most famous among the early critics of the theory was Rabbi David Zvi Hoffmann who, shortly after the publication of Wellhausen's research, published in 1903 a rebuttal entitled Decisive Evidence against the Graf-Wellhausen Theory. ${ }^{1}$ 
In the middle of the twentieth century, it seemed as if these radical critical theories were losing support. Umberto Cassuto attacked the documentary hypothesis in general in his research, and Yehezkel Kaufmann rejected the contemporary convention of dating the sources to a very late period. The extensive research that was increasing at that time on the archeology and history of the ancient Near East did not corroborate the propensity in critical biblical scholarship to date the sources to a late period. Scholars discovered that the Babylonian flood story corresponds to the biblical story as it exists, rather than to scholarly restorations of it. None of the many biblical fragments found at Qumran revealed the division between sources presented by the documentary hypothesis. In several universities, groups of scholars formed who engaged in literary and structural analyses of biblical narrative and biblical law from within, as they appear in the text, without focusing on their sources, their order, or the estimated dates of their composition.

However, towards the end of the century, radical critical theories again gained support. Today the division into sources still dominates biblical research, and the tendency to ascribe a late date to many biblical texts and to the final editing of the Torah has gained momentum. In the last few decades even popular forums directed to the wider public outside the academic ivory tower present a viewpoint supportive of literary and historical biblical criticism in its more radical forms. Summaries of the history of the Jewish people and the Land of Israel, intended for both students and the wider public, present biblical Israel as a nation that, according to the "scientific evidence," crystalized over time in the hill country of Canaan and subsequently invented the stories of the Patriarchs, the Exodus from Egypt, the revelation at Sinai, and the conquest of Canaan. ${ }^{2}$ The information card for the Aleppo Codex on display in the Shrine of the Book in Jerusalem informs the visitor that the five books of the Torah were created after the Babylonian exile. ${ }^{3}$

It is not my intention in this article to discuss the tenets of biblical criticism itself. After a brief discussion of its fundamental principles, I will propose an alternative theory.

A scientific principle is a principle that can be disproven. The first rule in any study is the clear distinction between the data and its interpretation. If no such distinction is made, the interpretation is presented as if it were the data itself, often creating a picture that is no more than wishful thinking, neither provable nor disprovable.

Interpretative suppositions, not facts, form the methodological basis of the documentary hypothesis, and for that reason it always has been, and still 
remains, a speculative theory. Another approach is to allow the sources to speak for themselves as they appear before us, "untouched by human hands." In this case, substantial evidence that a certain name or linguistic form is characteristic of a certain period or geographical area would constitute conclusive scientific evidence.

This type of work has been done over the last few decades in the study of the differences between standard biblical Hebrew and later biblical Hebrew. Avi Hurvitz, the most prominent scholar in the field, began his research on the subject with an investigation of one small detail, ${ }^{4}$ and then with his seminal work, The Transition Period in Biblical Hebrew. ${ }^{5}$ In his introduction, Hurvitz explains that his research is based on a comparison between biblical books that openly declare that they date from the Second Temple period, such as Esther, Ezra and Chronicles, and biblical books that describe only earlier events. Linguistic tendencies would be considered late only on the basis of accumulative and widespread evidence. These findings would be supported by comparison to other languages, in particular Aramaic and Persian, the language of Ben Sira, the Qumran Scrolls, and early rabbinic literature. On the basis of linguistic evidence culled by this method, he analyzed sources of unclear origin, such as the Psalms. For example, Hurvitz showed, on the basis of more than few occurrences, that biblical texts containing the word hedva (joy) are likely to be from the Second Temple period, and that the word butz (linen) in post-Exilic biblical Hebrew replaced its older synonyms shesh and bad, while malkhut (kingdom) replaced mamlakha. With these and similar findings, he examined other biblical books and proposed dates for various psalms. In another paper, on the basis of comparative analysis, he convincingly demonstrated that the cultic terminology of the "priestly" chapters in Exodus, Leviticus, and Numbers is completely different from that of parallel texts in Ezekiel, Ezra, and Chronicles, a factor that reduces the probability that these texts were written at the same time. ${ }^{6}$

\section{Studying the Names of God "Untouched by Human Hands"}

Both of the principal names of God, YHWH and Elohim, appear throughout the biblical periods in all of its literary registers and thus cannot be used as objective data with which to date biblical books, either absolutely or relatively. There are passages in which one name is favored and others in which both are used; it can be assumed that the most important considerations in choosing between the two names were literary or content-based. For example, each 
name expresses different aspects of God's appearance and rule on the earth. It is possible that in certain cases the decision was arbitrary or even based on a conscious desire for stylistic variety for its own sake. ${ }^{7}$ In a similar manner, the sages sometimes used the term ha-Kodesh (the Holiness) which developed into ha-Kadosh Baruch Hu (The Holy One Blessed be He), and other times haMakom (literally, "the Place"), or ha-Dibber ("the Speaking One," logos) which later developed into ha-Dibbur, just as people today say or write either "God," "The Lord," ha-Shem, or ha-Kadosh Baruch Hu.

The question that I would like to pose here is: Can the usage of the names of God provide intrinsic textual evidence of chronological development? In my opinion there are four such sets of data. Two of them have been long known but their significance has not been sufficiently emphasized. Several scholars have written about the third, and the fourth is apparently my own discovery.

\section{Shaddai}

The name Shaddai is mentioned in the Bible, according to the Masoretic text, forty-eight times. ${ }^{8}$ Many have attempted to explain its meaning and origin, but I am currently unaware of a cogent explanation for this name. ${ }^{9}$ I believe that it can be demonstrated that, in the biblical text as it appears before us, the original form of the name is El Shaddai, and Shaddai is its shortened form.

The distribution of occurrences of Shaddai is as follows:

Genesis - six times (of which five are El Shaddai);

Exodus - once: "I appeared to Abraham, Isaac, and Jacob as El Shaddai" (Exod. 6:3);

Numbers - twice (Balaam prophecies 24:4 and 16). In both verses within the phrase "Who beholds visions from the Almighty (Shaddai)." Both verses also include the name $E l$ ("God" or "the Almighty") in a parallel clause. In verse $24: 16$, God is also referred to as the "Most High";

Later Prophets - four times: twice in the phrase, "Ke-shod mi-Shaddai yavo" ("It shall come like havoc from Shaddai") (Isa. 13:6; Joel 1:15), and twice in the chariot passages in Ezekiel in similar phrases, "like the sound of Shaddai" (1:24) and "like the voice of El Shaddai when He speaks" (10:5);

Ruth - once: "when the Lord has dealt harshly with me, when Shaddai has brought misfortune upon me" (1:21); 
Psalms - twice: "When Shaddai scattered the kings" (68:15); "O you who dwell in the shelter of the Most High and abide in the protection of Shaddai" (91:1);

Job - thirty-one times, fifteen in parallel construct to $E l$, ten in parallel construct to Elo $a$, and six without a parallel. ${ }^{10}$

In addition to these references there are another two or three personal names containing the theophoric element shaddai: Ammishaddai, Zurishaddai, and apparently also Shedeur (see Num. 1).

It is very significant that only in Genesis (as well as the single occurrence in Exodus, which is a kind of summary of Genesis) does the name Shaddai appear in prose. Only one of the six occurrences in Genesis appears in a poem: "The God of your father who helps you, And Shaddai who blesses you" (Gen. 49:25). Throughout the rest of the Bible, the name always appears within a poetical context. The theophoric names including the morpheme shaddai could also attest to the prosaic rather than poetical use of the name; all three of these names are from the generation before the Exodus. In all six prose occurrences, the name appears as El Shaddai. In every other reference in the Bible, except one (Ezek. 10:5), the name appears as Shaddai without $E l$, although in a large percentage of the occurrences it appears in a parallel structure to El, and also appears parallel to Elyon (the Most High), and in one instance parallel to the Tetragrammaton. Furthermore, all of the references to El Shaddai in Genesis are in quotations of direct speech rather than in the narrative voice.

If we let the Bible speak for itself, it reveals that from the time of the Patriarchs until the Exodus from Egypt, the name El Shaddai was in active use in the spoken language. In certain cases, people integrated the name Shaddai as a theophoric basis for names they gave their children. The Torah itself only uses this name when it quotes direct speech from an earlier period. The authors of the later books used the name primarily as a special literary device in isolated cases, sometimes for the sake of alliteration and sometimes in search of a very evocative archaic word to strengthen the power of the poetry.

The word Shaddai is used in the book of Job much more frequently than in any other book. The explanation for this phenomenon depends on our understanding of the origin and dating of the book of Job. If we accept the opinion that the book is ancient and of non-Jewish origin, it is possible that the language of the book reflects an ancient dialect similar to the language of the forefathers. If we accept the opinion that the book was written in a later period, 
it can be surmised that Shaddai is one of the literary devices used by the author in a deliberate effort at archaization, similar to the advanced age of Job, the camels, and the kesita (Job 42:11), that embellish the narrative framework of the book and set it in the world of the Patriarchs.

To summarize, a survey of the history of the use of Shaddai and El Shaddai reveals natural and logical development, including a distinction between earlier and later periods, between poetry and prose, and between the narrative voice of the text itself and quotations of direct speech. This development is reflected also in personal names. Critical scholarship maintains that the author of the priestly source put the name El Shaddai in the mouths of the Patriarchs and in God's speech to them, yet was careful not to use this name himself to describe the Patriarchs or their exploits. He also had the insight to include personal names containing the morpheme shaddai specifically in the generation before the Exodus. This explanation is plausible, but it ascribes to this author exceptional finesse and attention to detail. I have attempted here to show that the Bible, seen as a unified whole, clearly reveals how the name Shaddai was initially used in the spoken language, fell out of use, and was later adopted as a literary expression.

\section{Tzva'ot (The Lord of Hosts)}

The name Tzva'ot used as an appellation of God is one of the most striking characteristics of biblical language. It is used 285 times in the Bible, usually in the phrase YHWH Tzava'ot (the Lord of Hosts) and about twenty times in the phrase YHWH Elohei Tzvaot. YHWH Tzva'ot serves as an appellation of the God of Israel in Samuel, Kings, and Psalms. Most of the prophets used it frequently (except for Ezekiel, Joel, Obadiah, and Jonah) from the beginning of the period of prophecy until Malachi. The phrase YHWH Tzva'ot is prototypical in prophecies, prayers, and every religious saying of the heroes of the Bible as well as the narrator.

Surprisingly, YHWH Tzva'ot — the Lord of Hosts-does not appear before the first chapter of 1 Samuel: "This man used to go up from his town every year to worship and to offer sacrifice to the Lord of Hosts at Shiloh" (1:3), and "And she made this vow: 'O Lord of Hosts, if You will look upon the suffering of Your maidservant" (1:11). The sages noticed this and concluded: "From the day that the world was created no one called God Tzvaot until Hannah." 1 Rabbi Yossi even deduced from this that Tzva'ot is not one of the holy names that should not be erased. In his opinion, the name is a shortened form of the 
construct form ha-Shem Elohei Tziv'ot Yisrael as it is written, "and deliver My ranks (tziv'otai), My people the Israelites, from the land of Egypt” (Exod. 7:4). The sages of the Talmud did not accept his opinion: "Shmuel said, 'The halakhah is not according to Rabbi Yossi." 12 The reason is clear: in all of the books of the prophets beginning with the book of Samuel and in the Psalms, Tzva'ot is a typical divine name.

Critical scholars who believe that the books of the Torah, Joshua, and Judges were written late, in the period of the monarchy, or even the beginning of the Second Temple period, need to explain how it is possible that the expression YHWH Tzva'ot is missing completely from all books preceding Samuel. If the author of the story of Abraham's servant's journey to Haran was writing in the period of the late prophets, why did he write, "and I will make you swear by the Lord, the God of heaven and the God of the earth" (24:3), rather than "I will make you swear by "the Lord of Hosts"? If the book of Deuteronomy was written in the time of Josiah, why did its author write "For the Lord your God is God supreme and Lord supreme, the great, the mighty, and the awesome God" (10:17), rather than "For the Lord of Hosts is God Supreme and Lord supreme ..."? Why does Joshua 22:22 read "God, the Lord God! God, the Lord God! He knows," rather than "The Lord of Hosts knows"? Why does the Song of the Sea read: "The Lord, the Warrior-Lord is His name!" (Exod.15:3), rather than "The Lord of Hosts is his name," a common phrase in the books of the prophets?

The answer to all these questions is that we have before us a clear case of natural linguistic development: a concept formed at the time of the writing of the book of Samuel or just before, a phrase that did not exist in Hebrew when the five books of the Torah, Joshua, and Judges were written. Quite simply, only the order in which the Bible presents itself can explain the distribution of the name Tzva'ot.

Alexander Rofé presents this question in all its complexity and then follows immediately with a declaration of the axiom: "We can reject outright the traditional explanation according to which the name Tzva'ot entered into use at the end of the period of the Judges. The documents written about the origins of the People of Israel are far from contemporaneous with the events they describe; most were written between the tenth and fourth centuries BCE." ${ }^{13}$ What then is the solution? Rofé reasons that later generations had theological reservations about the name Tzva'ot, whose original meaning was connected to the heavenly hosts and contained a syncretic element. The extant text is thus the product of an editorial purge that eradicated the name Tzva'ot 
entirely from the five books of the Torah, Joshua, and Judges. In his opinion, a clue to this can be found in the elimination of Tzva'ot in several instances in the passages copied from Samuel to Chronicles, as well as a significant reduction of occurrences of the expression in the versions of the book of Jeremiah in the Septuagint and the Dead Sea Scrolls (which, in the opinion of Rofé, are less authentic than the Masoretic text). However, Rofé does not convincingly explain why this resolute editing process was applied specifically to the Torah, Joshua, and Judges and not to other books of the Bible, and why other theologically problematic verses - such as "Who is like You, O Lord, among the celestials" (Exod. 15:11) —-were not expunged at the same time. It is particularly difficult to explain the totality of the phenomenon: no occurrences whatsoever until Samuel, compared with 285 occurrences from the beginning of Samuel until Malachi, as Rofé himself points out. ${ }^{14}$

\section{The Component YHW in Personal Names}

Most of the given names in the period of the monarchy in Judea and Israel are theophoric, containing the YHWH name in a shortened form YHW, or an even more shortened form YW or YH (the latter increased especially later in the Second Temple period). This reality can be perceived both in the Bible and the epigraphic sources. However, this phenomenon developed slowly. I will illustrate this point through an analysis of the books of the early prophets. In the five books of the Torah and Joshua there are only two persons whose names contain the YHWH element: Jochebed the mother of Moses, and Joshua son of Nun. Among the names mentioned in the book of Judges, three contain a shortened form of YHWH: Joash, the father of Gideon (Judg. 18: 13); Micah (written at the beginning of the narrative as Mikhayhu) from the hill country of Ephraim; and the youth who was his "father and priest," Jonathan (written Yehonathan), the son of Gershom (Judg. 17-18). ${ }^{15}$ In Samuel there are sixteen Israelites whose names contain $\mathrm{YW}$ or $\mathrm{YH}^{16}$ In the recounting of the life of Solomon in 1 Kings $1-11$, eleven ${ }^{17}$ out of (probably) sixty ${ }^{18}$ Israelite names contain $\mathrm{YHW} / \mathrm{YH} / \mathrm{YW}$. In the description of the period from the death of Solomon until the rise of Ahab (1 Kings 12-16) five out of eighteen Israelite names mentioned include YHW or its shortening. ${ }^{19}$ From here until the end of the book of Kings we find forty-nine names that do not contain YHW/YH/ YW, as compared with fifty-one that do. ${ }^{20}$

Out of the many names that appear in the five books of the Torah, only two contain shortening of YHWH. This corresponds well with the verse 
"I appeared to Abraham, Isaac, and Jacob as El Shaddai, but I did not make Myself known to them by My name" (Exod. 6:3). The family of Levi knew the YHWH name, and in one case gave a name containing it to a girl, Jochebed. ${ }^{21}$ The rest of the people, however, did not know the name. It was Moses who changed the name of his faithful servant Hosea son of Nun to Joshua (Num. 13:16) in a symbolic act that heralded a new age in the Israelite faith. Names containing the morpheme continued to appear infrequently until the era of the Judges; from this point onward they increased slowly, until they became the majority. No critical explanation can account for these statistics, which reflect the actual reality of the times. A later editor would not have invented a complete set of names without the YHWH element for the books of the Torah, and then afterwards sprinkled an increasing number of such names until they gradually became the majority.

There are two cases in which names without the YHWH component were changed to include it. (1) "Toi sent his son Joram [Yoram, containing the morpheme YW] to King David to greet him" (2 Sam. 8:10) contrasts with "he sent his son Hadoram to King David to greet him" (1 Chron. 18:10). (2) "Then Pharaoh Neco appointed Eliakim son of Josiah king in place of his father Josiah, changing his name to Jehoiakim [Yehoyakim, containing YHW]" (2 Kings 23:34). While the second example is difficult to explain, ${ }^{22}$ the first is easy to understand and is of fundamental importance. It is not likely that Toi, the king of Hamat, gave his son at birth a name that refers to $\mathrm{YHWH}$, the God of Israel. It would therefore appear that Hadoram was his original name, after the name of the Aramaic god Hadad, and Toi changed it to Joram in order to find favor in the eyes of his protector David.

And another surprise: it can be concluded from the data mentioned above that most people in Judah and Israel in the period of the monarchy, though accused by the prophets of forsaking $\mathrm{YHWH}$ and worshipping Baal and Astarte, chose to include the name of YHWH in their children's names.

\section{Adonai}

From the middle of the Second Temple period until today, it has been an accepted practice among Jews to pronounce the word Adonai (meaning "my Lord") in place of the name $\mathrm{YHWH}$, and as a result readers have difficulty distinguishing between the original Adonai and YHWH. In fact, Adonai is quite rare in the written text of the Bible. In contrast to the more than 6,800 occurrences of the Tetragrammaton $\mathrm{YHWH}$ in the Bible, Adonai appears only some 
440 times, ${ }^{23}$ of which approximately three hundred are in the phrase Adonai YHWH (pronounced Adonai Elohim), five in the phrase "YHWH Adonai" (pronounced Elohim Adonai), and 134 times without YHWH. (The Masorah indicated this in the notation 134 vaddain).

I have discovered a major difference between the use of Adonai in the Torah, Joshua, Judges, and Samuel and its use in the subsequent biblical books, from Isaiah, Amos, and Kings until the end of the biblical era. ${ }^{24}$ Adonai only becomes an actual name of God in the books of Isaiah, Amos, Micah, and Kings. ${ }^{25}$ For example, in Amos, "He showed me: behold, the Lord (Adonai) was standing beside a wall built with a plumb line, with a plumb line in his hand" (7:7), and "I saw the Lord (Adonai) standing beside the altar" (9:1); in Isaiah, "In the year that King Uzziah died, I beheld the Lord (Adonai) seated on a high and lofty throne" (6:1); and in Kings, "For the Lord (Adonai) had caused the Aramean camp to hear a sound of chariots, a sound of horses" (2 Kings 7:6). Before this period, it was used only in those functions also served by the title adoni (my lord) when addressing human beings. In the former books of the Bible Adonai could be found only within a quotation of direct speech, never in the narrative voice, and always within a plea of supplication, sometimes with the suppliant expression $b i$ - or the exclamation ahah.

On the other hand, it must be noted that nowhere in the Bible is the term adoni (my Lord) used in addressing God, as might be expected. From this we can conclude that the word Adonai was originally no different than adoni. Both were terms used to address someone of a higher status. From a linguistic perspective, biblical Hebrew includes both the singular form adon and adonim, a plural form used as a singular noun (the pluralis majestatis) as in "And I will place the Egyptians at the mercy of a harsh master (adonim)" (Isa. 19:4), and "And if I am a master (adonim), where is the reverence due Me? - said the Lord of Hosts to you" (Mal. 1:6). These forms are similar to ba'al/be'alim and Elo ${ }^{a} h / E l o h i m$. There is an interesting differentiation in use between adon and adonim. When the word stands alone, adon is the common form and adonim is rare. However, when the word has a personal pronoun suffix, the word base becomes plural, ${ }^{26}$ as in adoneinu, adonekha, adonekhem, adonav, ${ }^{27}$ adoneha, and adoneihem. The word remains singular only in first-person singular (adoni). Therefore, Adonai is really the most natural form of address, ${ }^{28}$ and adoni is actually the irregular form. It seems that at a certain time, probably quite early, a linguistic distinction was made between the term used to address a person and the same term when used to address $\operatorname{God}^{29}$ by designating the form derived from the plural to God, and that derived from the singular to people. ${ }^{30}$ Once 
there was a specific term for addressing God, it naturally developed into an actual name of God, though its previous function was not effaced. This development occurred apparently in the time of Isaiah and Amos. In biblical books from before this period, both forms of the word, Adoni and Adonai, are still only terms of addressing a superior, whether human or divine. ${ }^{31}$ This distinction between the biblical books corresponds to the order in which they appear in the Bible, rather than that hypothesized by scholars.

\section{Conclusion}

Four facets of names of God reveal clear internal development within the classical biblical period: (1) El Shaddai was used in oral speech only until the Exodus from Egypt. In later periods, the name Shaddai existed as an archaic term used, infrequently, by prophets and poets. (2) The expression YHWH Tzva'ot (the Lord of Hosts) originated only in the time of the book of Samuel, and was in use from then until the composition of the books of Haggai, Zechariah, and Malachi. (3) The first two cases of the theophoric element YHW/YH/YW in personal names occurred just before and during the life of Moses. From that point, it increased gradually in frequency until the period of the late monarchy, by which time it was included in more than half of all personal names. (4) The name indicating lordship, Adonai, was initially a term of supplicatory address and became a name of God in the eighth century BCE.

All of these developments can be easily understood and explained according to the chronology that corresponds to the order in which the Bible presents itself, namely: the five books of the Torah followed by, in order, Joshua, Judges, Samuel, and Kings, as whole, complete books written in succession. The prevalent critical approach, which rejects this order, will have great difficulty explaining the data presented here.

\section{Endnotes}

1. D. Hoffmann, Die wichtigsten Instanzen gegen die Graf-Wellhausensche Hypothese (Berlin: Druck von H. Itzkowski, 1903-1916).

2. For example, Shmuel Ahituv, "Kibush Eretz Kana'an me-Behina historit" [The conquest of Cana'an from a historical perspective] in Yehoshua im Mavo u-Perush [Joshua: Introduction and commentary], vol. 6 of Mikra le-Yisra'el [A Bible commentary for Israel] (Tel Aviv: Am Oved, 1995), 45-53; Nadav Na'aman, "From Settlement of the Land to the Destruction of the Temple," in Israel: People, Land, State: A Nation and its Homeland, ed. Avigdor Shinan et al., trans. Eliyahu Green (Jerusalem: Yad Ben-Zvi, 2005), 20-37; A. F. Rainey and R. S. Notley, The Sacred Bridge: Carta's Atlas of the Biblical World (Jerusalem: Carta, 2006), 111-112. 
3. After both Professor Yosef Ofer and I voiced our objections, Dr. Adolfo Roitman, the curator of the Shrine of the Book, agreed to add the words "according to the opinion of most scholars" to the information card. See Yoel Elitzur and Yosef Ofer, "Ha-Heichal ve-Hasefer: Rishmei Siur be-Heikhal ha-Sefer le-aḥar Petiḩato Meḥadash" [The shrine and the book: Impressions from an excursion to the Shrine of the Book after its re-opening], Appendix: "Heikhal ha-Sefer ve-Hivatzrutah shel Torat Moshe" [The Shrine of the Book and the creation of Moses' Torah], Al-Atar 13-14 (2006): 218-220.

4. Avi Hurvitz, "The Usage of 'Shesh' and 'Butz' in the Bible and its Implication for the Date of P," Harvard Theological Review 60 (1967) 117-121.

5. A. Hurvitz, Bein Lashon le-Lashon: le-Toldot Lashon ha-Mikra be-Yimei Bayit Sheni [The transition period in Biblical Hebrew: A study in post-Exilic Hebrew and its implications for the dating of the Psalms] (Jerusalem: Mosad Bialik, 1972). For a summary of this subject see A. Hurvitz, "Biblical Hebrew, Late," in Encyclopedia of Hebrew Language and Linguistics, ed. G. Khan et al. (Leiden: Brill, 2013), 1:329-338.

6. A. Hurvitz, "Dating the Priestly Source in Light of the Historical Study of Biblical Hebrew a Century after Wellhausen," Zeitschrift für die alttestamentliche Wissenschaft 100 Supplement (1998): 88-100.

7. See the important and well-founded opinions of Abba Bendavid on this matter: Abba Bendavid "Ta'arovet Homrei ha-Lashon ba-Mikra" [The mixing of linguistic material in the Bible], in Leshon Mikra u-Leshon Hakhamim [Biblical Hebrew and Mishnaic Hebrew] (Tel Aviv: Dvir, 1967), 13-59, and especially his summary on pp. 58-59.

8. E. Knauf, "Shadday" in Dictionary of Deities and Demons in the Bible, eds. Karel Van Der Toorn, B. Becking, and P. W. Van der Horst (Leiden: Brill, 1999), 749-753. Knauf presented the data professionally and clearly, but hastened to date them in accordance with the conventional critical theories.

9. Ancient translators, classical commentators and modern scholars have been long perplexed by the meaning of the name Shaddai. Some ancient translators have transliterated rather than translated the name, perhaps assuming that it is a personal name, or perhaps due to the difficulty in translating it. Others simply bypassed it. Some understood the name to signify power and might. A widespread Jewish etymological interpretation explains the name as a compilation of the letter shin and the word dai (enough). This explanation is used by Aquila, Symmachus, and Theodotion, Bereshit Rabbah, the late Samaritan translation, Rav Saadia Gaon, and Rashi. Ibn Ezra quite rightly rejects this interpretation: "I do not understand the meaning of this interpretation. How can a name be called 'that which is enough'?" In modern scholarship, many etymologies and connections to Near Eastern cultures have been suggested for Shaddai. I have found eight different proposals in the research literature. The opinion generally accepted by scholars since it was proposed by Delitzsch is that the name is connected to the Akkadian word šadû meaning "mountain." Regarding the nature of the connection between Shaddai and "mountain," there are several suggestions. "Mountain" or "big mountain" is sometimes an epithet for a deity in Mesopotamian sources. Šadû can also refer to "an uninhabited land," "desert", or "plain," perhaps after the name of the arid mountains outside the lush plain of the Euphrates and Tigris Rivers. Therefore, there are those who argue that Shaddai is the god of the desert. Šaddā' $u$ or šaddû'a meaning "mountain dweller" is derived from šadû (Ignace J. Gelb et al, eds., The Assyrian Dictionary of the Oriental Institute of the University of Chicago [Chicago: Oriental Institute, 1956-2006], Vol. $17, \check{S} 1,43)$. According to Albright, this could be the original meaning of the name Shaddai. Bibliography for the information in this note: Eliezer Ben Yehuda, Milon ha-Lashon ha-Ivrit ha-Yeshanah ve-ha-Hadashah [A complete dictionary of Ancient and Modern Hebrew], ed. 
N. H. Tur-Sinai (Jerusalem-New York-London: Thomas Yoseloff, 1959), 7:6911-6912. L. Koehler and W. Baumgartner, Lexicon in Veteris Testamenti Libros (Leiden: Brill, 1985), 950; L. Koehler and W. Baumgartner, The Hebrew and Aramaic Lexicon of the Old Testament (Leiden: Brill, 1991), 1420-1422. See Knauf, "Shadday," note 8.

10. In Job there is also a hapax legomenon in an obscure verse that some have seen as a plural form of Shaddai: "Be in fear of the sword, For [your] fury is iniquity worthy of the sword; Know there is a judgment!" (Job 19:29). The last word in the verse is written $\check{s} d w n$ and read as shadoon.

11. Babylonian Talmud, tractate Berakhot 31b; Midrash Samuel 2.

12. Babylonian Talmud, tractate Shevu'ot 35b.

13. Alexander Rofé, "Ha-Shem 'ha-Shem Tzva'ot' ve-ha-Mahadura ha-Ktzara shel Sefer Yirmiyahu" [The name ha-Shem Tva'ot and the brief edition of Jeremiah], Mo'ed 21 (2013): 21. I would like to thank the reader of this article in the peer review process of the Hebrew version of this volume who brought Rofés important work to my attention.

14. "Anyone familiar with the process of editing knows well how difficult it is to do the job thoroughly. Therefore, it is no wonder that most of the editing in the Bible is incomplete." Rofé, "Ha-Shem," 30.

15. Joash the father of Gideon worshipped Ba'al, while Micah and Jonathan apparently worshipped the God of Israel, although through the intermediary devices of a sculptured image, a molten image, ephod, and teraphim!

16. It is possible that the name Zeruiah should also be included. Out of forty-nine personal names mentioned in the lists of David's warriors in 2 Samuel 23, according to the Masoretic text, six names include YHW/YH/YW: Joab, Benaiah, Jehoiada, Benaiah of Pirathon, Jonathan, and Uriah.

17. Again, it is unclear if Zeruiah was a theophoric name.

18. Perhaps we can reduce the number to fifty-seven if we assume that the two Nathans and/or three Ahiluds in these chapters were identical.

19. I did not include older names mentioned here, such as David and Solomon. I included Abijam (Aviyam) in the list of names that do not contain the YHWH component. In Chronicles the name appears as Avia, and in this form it is included in the list of names containing YH. This would appear to be connected to the increase in the names including the YHVH element. A more interesting example is the way in which Jeroboam son of Nebat revived the names of the sons of Aaron. Nadab and Abihu (Avihu) became Nadab and Abijah (Avia). The name of the second son in the Torah does not include YHVH element, while the name of the son of Jeroboam does include it. This point was noted by I. M. Grintz, Mehkarim be-Mikra [Studies in the Bible] (Jerusalem: Marcus, 1979), 144.

20. This subject was addressed briefly by B. Porten, "Shem, Shemot Etzem Pratiyim be-Yisrael" [Names, proper nouns in Israel], Entzeklopedia Mikrait [Encyclopaedia biblica] (Jerusalem: Mosad Bialik, 1968), 8:49. In a television program presented by Dov Elbaum that aired on May 10, 2013, Professor Aaron Demsky cogently and thoroughly discussed both this subject and the divine names Shaddai and El Shaddai, as well as the personal names Shedeur, Zurishaddai, and Ammishaddai (Num. 7). His approach was similar to the approach presented here.

21. The language of the verse is precise: "but I did not make Myself known to them by My name." It means that the name already existed but was not known to the people.

22. See William Emery Barnes, The Second Book of Kings (The Cambridge Bible; Cambridge: The University Press, 1911), 136; James A. Montgomery, A Critical and Exegetical Commentary of the Books of Kings, ed. Henry Snyder Gehman (New York: Charles Scribner's Sons, 1951), 
550-551; Yehuda Kiel, Melakhim [Kings], vol. 9 of Torah, Nevi'im, Ketuvim im Perush Da'at Mikra [Torah, Prophets, and Writings with the Da'at Mirka commentary], ed. Yehuda Kiel et al (Jerusalem: Mosad Harav Kook, 1981), 814. Mordechai Cogan and Hayim Tadmor, II Kings, vol. 11 of the Anchor Bible (New York: Doubleday, 1988), 303.

23. Biblical dictionaries, grammar books, and research literature that address this topic usually refrain from citing precise numbers. According to Otto Eissfeldt ("?ādhôn; adhōnāi," Theological Dictionary of the Old Testament, ed. G. J. Botterweck and H. Ringgren, [Grand Rapids, MI: William B. Eerdmans, 1974], 62), Adonai appears 449 times in the Bible. EvenShoshan (A New Concordance of the Bible, [Jerusalem: Kiryat Sefer, 1989], 17-18) lists 425 occurrences. I took the trouble to count the number listed in Solomon Mandelkern's concordance (Veteris Testamenti Concordantiae Hebraicae atque Chaldaicae, ed. F. Margolin and M. Gottstein [Jerusalem and Tel Aviv: Schocken, 1971], 16) and they total 422. In the digitalized concordance "Snopi" (http://www.snopi.com/xDic/Bible.aspx) in which the verses appear in their entirety, I counted 433 occurrences, and it is clear that the actual number is not less than this. The reckoning of "134 vaddain" of Adonai names that appear alone without $\mathrm{YHWH}$, mentioned by the masorah, fits the data as cited in Mandelkern's Concordance.

24. I have published a detailed article on this subject. See Yoel Elitzur, "The Divine Name ADNY in the Hebrew Bible: Surprising Findings," Liber Annuus 65 (2015) 87-106.

25. The transition of a word from a term of address in the first person to a general noun or title is known in several languages and cultures. Examples are Rabbi in the language of the sages, Mari in various Aramaic dialects, and Monsieur, Madame, and Madonna in European languages, as pointed out by various scholars who have studied the subject.

26. In construct state as well, in most phrases, the basis is the plural: Adonei Yosef (Gen. 39:20); adonei ha-aretz (Gen. 42:30,33); adonei ha-har (1 Kings 16:24), adonei ha-adonim (Deut. 10:17, Ps. 136:3), all together six times. On the other hand, the phrase adon kol ha'aretz based on the singular form, appears also six times (Josh. 3:11,13, Mic. 4:13, Zech. 4:14, 6:5, Ps. 97:5).

27. The word adono appears once in the Bible in writing, but is read differently: "Do not inform on a slave to his master [adono]" (Prov. 30:10).

28. The word ostensibly should be written with a patah, but when it was turned into a name, its vowel lengthened in accordance with the rules of the phonology of names, as in the cases of names such as Natan, Yitzhak, and Yigal.

29. Another example of the differentiation between sacred and secular use can be found in the traditional vocalization of the word abir (warrior, strong). It appears six times in the Bible vocalized as avir in phrases describing God, such as avir Yaakov or avir Yisrael. In contrast, in secular contexts the vocalization is abbir: abbir ha-ro'im, abbirim, abbirekha, abbirei lev (seventeen times). I would like to thank the reader in the peer review process who brought this example to my attention. I afterwards became aware of the article by Ezra Zion Melammed, "Shimushi Lashon ba-Mikra ha-Miuhadim le-ha-Shem" [Linguistic uses in the Bible specific for the Lord], Tarbiz 18 (1948): 1-18. On the first page the author points out the distinction between adoni and Adonai, and on the second page the distinction between abir and avir, and adds many more examples (not all of which are equally convincing).

30. A similar development occurred much later with the phrase ribono shel olam (Master of the World) (in manuscripts of the Mishnah, rabbuni). In classical rabbinic literature, this is also a form of address conveying the subservience with which a person appeals to the Creator. In our time (apparently due to the influence of Yiddish), ribono shel olam is used also as an actual epithet of God. 
31. The conclusions that I have presented here are, in my opinion, derived directly from the data. Scholars who researched the subject before me usually missed the dramatic change that occurred in the status of the word Adonai in the eighth century BCE. W. W. F. Baudissin commented that, in the five books of the Torah, Adonai is used only as a form of addressing God (Kyrios: als Gottesname im Judentum und seine Stelle in der Religions-geschichte [Giessen: Topelmann, 1929], 2:18; quoted by Eissfeldt, Theological Dictionary, 67). However, he did not realize that this situation continued until the end of the book of Samuel, and most importantly did not regard this observation as particularly important.

In the classical scholarly literature, the prevalent opinion was indeed that the word originated in the form of address meaning "My Lord!" Gustaf Dalman went so far as to suggest that the word be removed from the text in cases in which it did not conform to this interpretation, and posited that in the original sources these verses contained the $\mathrm{YHWH}$ morpheme, which was changed to Adonai by later scribes. See Gustaf Dalmman, Studien zur Biblischen Theologie: Der Gottesname Adonaj und seine Geschichte (Berlin, 1889), 33.

Others (for example, Gesenius' Hebrew Grammar, second ed., ed. E. Kautzsch, trans. A. E. Cowley [Oxford: Clarendon Press, 1910], 441) were less extreme and explained that the word was petrified in this form, as were other forms of address in various languages (as I pointed out in note 25 above). H. Bauer and P. Leander (Historische Grammatik der Hebräischen Sprache des Alten Testamentes [Halle; Max Niemeyer, 1922], 16, 253, 469, 502) proposed a clever and radical explanation: Adonai did not originate from adon, but rather the opposite: Adonai in the sense of "lord" is a word introduced into Hebrew from an unknown source. Over the course of time, speakers of the language came to the conclusion that the suffix of the word is the form of address in first person singular of a plural object, and in error derived from this the noun adon (lord).

In the last few decades, many have cited the opinion of Otto Eissfeldt, who pointed out four occurrences in Ugaritic sources in which we find an addition of the letter yod at the end of nouns. (Oswald Loretz, who followed his approach, added a fifth example.) According to Eissfeldt, the purpose of this suffix is to strengthen and emphasize the noun, and it may be assumed that it is to be pronounced "ayy." He proposes that this is also the primary meaning of the suffix -ai in the Hebrew name Adonai (and, eventually, the form of address Adoni in reference to God was also adapted to this form). For discussions and references to opinions mentioned in this footnote, see Eissfeldt, 59-72; K. Spron, "Lord," in Dictionary of Deities and Demons in the Bible, 531-533; M. Rösel, Adonaj-Warum Gott 'Herr' genant wird (Tübingen: Mohr Siebeck, 2000), 17-21. I would like to thank Professor Lutz Doering of the University of Münster who brought Rösel's book to my attention. 